\title{
Nuclear reprogramming in mammalian somatic cell nuclear cloning
}

\author{
H. Tamada and N. Kikyo \\ Stem Cell Institute, Division of Hematology, Oncology and Transplantation, Department of Medicine, University of Minnesota, \\ Minneapolis, MN (USA)
}

\begin{abstract}
Nuclear cloning is still a developing technique used to create genetically identical animals by somatic cell nuclear transfer into unfertilized eggs. Despite an intensive effort in a number of laboratories, the success rate of obtaining viable offspring from this technique remains less than $5 \%$. In the past few years many investigators reported the reprogramming of specific nuclear activities in cloned animals, such as genome-wide gene expression patterns, DNA methylation, genetic imprinting, histone modifications and telomere length
\end{abstract}

regulation. The results highlight the tremendous difficulty the clones face to reprogram the original differentiation status of the donor nuclei. Nevertheless, nuclei prepared from terminally differentiated lymphocytes can overcome this barrier and produce apparently normal mice. Study of this striking nuclear reprogramming activity should significantly contribute to our understanding of cell differentiation in more physiological settings.

Copyright $\odot 2004$ S. Karger AG, Basel

\section{Introduction}

Given the enormous complexity of the gene regulatory pathways, it is remarkable that the entire cell differentiation program can be completely erased and properly re-established in somatic cell nuclear cloning (Hochedlinger and Jaenisch, 2002b; Oback and Wells, 2002). Nuclei taken from terminally differentiated B cells can produce the entire body of embryos with apparently normal functions as long as the extra-embryonic tissues are supplied externally by the tetraploid blastocysts (Hochedlinger and Jaenisch, 2002a). Simple nuclear injection was insufficient for the $B$ cell nuclei to acquire pluripotency and the clones had to pass through ES cells to produce live pups in this experiment; nevertheless, this remarkable finding indicates that differentiated nuclei can be de-differentiated in the oocyte and embryonic environment. Nuclear cloning is

This work is supported by the NIH (GM068027), the American Cancer Society (IRG58-001-43-IRG40), the Minnesota Medical Foundation, and the Graduate School of the University of Minnesota.

Received 6 October 2003; manuscript accepted 12 November 2003.

Request reprints from: Dr. Nobuaki Kikyo, Stem Cell Institute

Division of Hematology, Oncology and Transplantation

Department of Medicine, University of Minnesota, MMC 716

420 Delaware St. SE, Minneapolis, MN 55455 (USA)

telephone: +1-612-624-0498; fax: +1-612-624-2436

e-mail: kikyo001@tc.umn.edu arguably one of the most powerful experimental systems to study the reprogramming of cell differentiation. In Xenopus cloning, all active genes in the donor nuclei are shut off soon after nuclear transfer is completed. Several hours after nuclear transfer, embryonic nuclei start to express development specific genes that follow the normal time course of the zygotic gene activation (Chan and Gurdon, 1996; Byrne et al., 2002). One can argue that this genetic reprogramming is simply due to dilution of the donor nuclear components by the proteins and RNA stored in the large frog eggs. However, that argument is not convincing in the case of mouse cloning, where reprogrammed gene expression initiates as early as the 2-cell stage in tiny embryos. Although the success rate of animal cloning is still extremely low (Table 1), extensive reprogramming of differentiation at the cellular level is accomplished in aborted embryos that contain well differentiated tissues. Since such a drastic and rapid nuclear reprogramming is rare in living cells, nuclear cloning will provide a unique window to dissect the cell differentiation mechanisms.

The cloning of Dolly the sheep in 1997 triggered a wide interest in mammalian cloning (Wilmut et al., 1997) followed by a number of mammalian clones created from adult cell nuclei as shown in Table 1. The recent progress in mammalian cloning needs to be interpreted in the context of the long cloning history initiated by Briggs and King, who created swimming frog tadpoles by injecting blastomere nuclei into unfertilized eggs in 1952 (Briggs and King, 1952). In the pre-Dolly era, key 
Table 1. List of cloned mammals

\begin{tabular}{|c|c|c|c|}
\hline Reference & Species & Donor Cells & $\begin{array}{l}\text { Cloning Efficiency } \\
\text { (Live birth/Manipulated oocytes) (\%) }\end{array}$ \\
\hline Wilmut et al., 1997 & Sheep & Mammary epithelial cells & $1 / 277(0.4)$ \\
\hline Wakayama et al., 1998 & Mouse & Cumulus cells & $41 / 2468(1.7)$ \\
\hline \multirow[t]{2}{*}{ Kato et al., 1998} & Bovine & Cumulus cells & $5 / 99(5.0)$ \\
\hline & & Oviductal cells & $3 / 150(2.0)$ \\
\hline Cibelli et al., 1998 & Bovine & Fetal fibroblasts & $4 / 276(1.4)$ \\
\hline Baguisi et al., 1999 & Goat & Fetal fibroblasts & $3 / 285(1.1)$ \\
\hline Onishi et al., 2000 & Pig & Fetal fibroblasts & $1 / 210(0.5)$ \\
\hline Polejaeva et al., 2000 & Pig & Adult granulosa cells & $5 / 183(2.7)$ \\
\hline Betthauser et al., 2000 & Pig & Fetal cells & Not available \\
\hline Chesne et al., 2002 & Rabbit & Cumulus cells & $6 / 1852(0.3)$ \\
\hline Shin et al., 2002 & Cat & Cumulus cells & Not available \\
\hline Woods et al., 2003 & Mule & Fetal fiborblasts & $1 / 334(0.3)$ \\
\hline Galli et al., 2003 & Horse & Fibroblasts & $1 / 841(0.1)$ \\
\hline Roh et al., 2003 & Rat & 2-cell stage embryos & $6 / 139(4.3)$ \\
\hline Zhou et al., 2003 & Rat & Fibroblasts & Not available \\
\hline
\end{tabular}

concepts, such as the importance of cell cycle compatibility between the donor nuclei and host eggs, and the progressive decrease of cloning efficiency related to the donor differentiation stage, were already established (Gurdon, 1986; Sun and Moor, 1995). One factor that has accelerated the cloning research is the successful mouse cloning by Wakayama and colleagues using adult cumulus cell nuclei (Wakayama et al., 1998). Until then, the blastocyst was believed to be the last stage compatible as a nuclear cloning donor (Solter, 2000). Supported by a wealth of background information, mouse cloning enabled us to investigate reprogramming of genetic imprinting, reactivation of the inactive $\mathrm{X}$ chromosome, and potential problems of ES cells as the source of the donor nuclei, none of which were possible with other species (see below for references).

In addition to low birth rate, live cloned animals demonstrate a variety of pathological conditions such as respiratory failure, placental dysfunctions and large offspring syndrome (Young et al., 1998; Rhind et al., 2003). It is usually difficult to trace the origin of these ailments to a few responsible genes. Probably, they reflect the cumulative effects of many faulty gene expressions. Because these abnormalities were not passed on to the offspring of the cloned mice, these phenotypes represent aberrant gene expression by deficient epigenetic reprogramming rather than genetic changes in cloned animals (Tamashiro et al., 2002). Even though nuclear reprogramming is a complicated process, by focusing on a certain aspect of the nuclear events, it is possible to dissect and understand the basic science behind the reprogramming as demonstrated by our recent finding of the nucleolar disassembly in egg cytoplasm (Gonda et al., 2003).

In this review, we will discuss the reprogramming of genome-wide gene expression, DNA methylation, histone modifications and telomere length regulation that occur during nuclear cloning. Reflecting the recent wide attention to the cloning field, numerous insightful reviews are available on various aspects of nuclear cloning. The readers are recommended to refer to the following papers: Campell (1999), Gurdon (1999), Wakayama and Yanagimachi (1999), Kikyo and Wolffe (2000), Hochedlinger and Jaenisch (2002b), Oback and Wells (2002), Mullins et al. (2003) for a more general account of clon- ing, McLaren (2000), Solter (2000), Gurdon and Byrne (2003) for the historical background, Jaenisch et al. (2002), Dean et al. (2003) for epigenetic reprogramming and Wade and Kikyo (2002) for biochemistry of the nuclear reprogramming.

\section{Abnormal gene expression in cloned animals}

Several groups have compared gene expression patterns in clones and control animals as summarized in Table 2. By analyzing expression of eight developmentally important genes in cloned blastocysts, Wrenzycki and colleagues reported that several genes were properly activated in the blastocysts, but with a marked difference in the gene expression levels (Wrenzycki et al., 2001). These differences were found to be dependent on parameters in the nuclear transfer procedure, including the activation protocol, the cell cycle of the donor cells and the passage number of the donor cells. Daniels and colleagues also reported a similar finding based on the study of a different set of genes specific to early embryonic development (Daniels et al., 2000, 2001).

To understand the genome-wide difference in the gene expression patterns between cloned mice and fertilizationderived controls, a DNA microarray was employed using RNA isolated from placentas and livers of these mice (Humpherys et al., 2002). The result showed that less than $3 \%$ of over 12,000 genes were expressed abnormally in the clone's placentas. Placentas tend to overgrow in clones, but there was no clear relationship between the additional growth and the aberrantly expressed genes. The livers of the clones showed a less conspicuous abnormality in gene expression than placentas, which may occur as liver is a more homogeneous tissue with smaller number of differentiated cell types than placenta. It is impressive that more than $97 \%$ of the genes could be properly silenced or activated in the cloned embryos in this comprehensive genome-wide analysis. However, it is important to note that this study examined RNA isolated from a whole tissue; and by doing so, an irregularity of the gene expression in each cell may have been averaged (see below for improper spatial distribution of Oct4 as an example). 
Table 2. Aberrant gene expression patterns in cloned mammals

\begin{tabular}{|c|c|c|c|c|c|}
\hline Reference & Donor & Cells & Number of the tissue & $\begin{array}{l}\text { Aberrantly expressed genes } / \text { total } \\
\text { number of genes examined }\end{array}$ & Detection method \\
\hline Daniels et al., 2000 & Bovine & Granulosa cells & 2-cell embryo to blastocyst $(4-10)$ & $3 / 7(42.9 \%)$ & RT-PCR \\
\hline Daniels et al., 2001 & Bovine & Fetal epithelial cells & Blastocyst (62) & $1 / 4(25 \%)$ & RT-PCR \\
\hline Humpherys et al., 2002 & Mouse & ES cells & $\begin{array}{l}\text { Placenta (12) } \\
\text { Liver (13) }\end{array}$ & $\begin{array}{l}221 / 12,654(1.7 \%) \\
26 / 12,654(0.2 \%)\end{array}$ & Microarray \\
\hline & & Cumulus cells & Placenta (14) & $286 / 12,654(2.3 \%)$ & \\
\hline Suemizu et al., 2003 & Mouse & ES cells & Placenta (2) & $\begin{array}{l}\text { Clone 1: 1,807/15,247 (11.9\%) } \\
\text { Clone 2: 1,964/15,247 (12.9\%) }\end{array}$ & Microarray \\
\hline
\end{tabular}

a Gene expression is defined as aberrant in the microassay analysis when the gene expression level in the cloned mice is 2 -fold higher or lower than in the controls derived from fertilization.

The transcription factor Oct4 is essential to maintain pluripotency of early mouse blastomeres (Pesce and Scholer, 2001). Oct4 is exclusively expressed in germ cells and early embryonic cells; therefore, it must be reactivated soon after nuclear transfer in the somatic cell clones. Indeed, more than $80 \%$ of the cumulus cell clones reactivated Oct 4 at the correct stage, but $54.7 \%$ of the clones showed aberrantly high level of the Oct 4 transcript in the trophectoderm at the blastocyst stage when Oct4 expression is normally limited to the inner cell mass (Boiani et al., 2002). Recently, it was reported that Oct4 expression could be specifically reactivated in mouse thymocyte nuclei and human lymphocyte nuclei injected into Xenopus oocytes, suggesting that the regulatory mechanisms for this pluripotency-specific gene are probably evolutionarily conserved (Byrne et al., 2003). Another pluripotency gene Nanog is a newly discovered homeoprotein specifically expressed in morulae, inner cell mass and ES cells (Chambers et al., 2003; Mitsui et al., 2003). Nanog is required to maintain these cells pluripotent, independently of the LIF/Stat 3 pathway used by the Oct 4 signaling system. It remains to be examined if Nanog demonstrates correct spatial and temporal profiles of reactivation in cloned embryos.

\section{Reprogramming of DNA methylation and imprinting}

DNA methylation of cytosine at the $\mathrm{CpG}$ dinucleotides plays vital roles in the regulation of gene expression in mammalian development (Bird, 2002; Li, 2002). DNA methylation suppresses gene expression by recruiting methyl-CpG binding proteins, such as MeCP2, MBD1, MBD2 and MBD3, as well as associated histone deacetylases, co-repressor proteins and chromatin remodeling machineries to the promoter of specific genes. At least three DNA methyltransferases are involved in the methylation of new $\mathrm{CpG}$ sites and maintenance of the already methylated $\mathrm{CpG}$ during DNA replication. Ubiquitously expressed DNMT1 functions primarily as a maintenance methylase that methylates $\mathrm{CpG}$ sites on the newly synthesized DNA strand copying the existing methylation pattern on the template DNA strand. Developmentally regulated DNMT3a and DNMT3b are responsible for methylation of new $\mathrm{CpG}$ sites to establish de novo $\mathrm{CpG}$ methylation patterns, especially in early development and germ cell development.
The DNA methylation pattern shows global changes during early mouse development (Dean et al., 2003). Upon fertilization a majority of the sperm-derived genomic DNA is rapidly demethylated before the onset of DNA replication by an uncharacterized active mechanism (Mayer et al., 2000; Santos et al., 2002). In contrast, oocyte-derived DNA is passively demethylated only after DNA replication initiates, by the nuclear exclusion of DNMT1. The global level of DNA methylation remains at the lowest level in the morula and blastocyst stages until implantation, when sudden genome-wide de novo methylation occurs by DNMT3a and DNMT3b. The genomewide demethylation and remethylation in early embryos seems to be conserved across species as observed in cow, rat and pig, although their timing with respect to developmental stages is slightly different (Dean et al., 2001). Successfully cloned embryos have to follow these methylation dynamics to erase the tissue-specific DNA methylation pattern and establish a new embryo-specific DNA methylation pattern on numerous genes.

A majority of the cloned bovine embryos show a gross abnormality in the genome-wide DNA methylation level and DNA methylation patterns on various repetitive sequences when compared with fertilization-derived controls (Table 3 ). The DNA methylation level in clones can be higher or lower than that in the control embryos depending on the donor cell types, target DNA sequences, examined embryonic stages and detection methods. The abnormality of the DNA methylation level is also substantially variable among individual clones (Kang et al., 2001a) and extremely abnormal embryos may have died before the analysis was done. Indeed, DNA methylation was undetectable in six out of nine spontaneously aborted bovine clones, but the methylation level was normal in the clones that survived to adulthood (Cezar et al., 2003).

Bovine somatic nuclei are resistant to the erasure of DNA methylation in early embryogenesis described above and the clones have a tendency to preserve the DNA methylation patterns inherited from the donor cells (Bourc'his et al., 2001; Dean et al., 2001). Re-establishment of DNA methylation was also potentially deregulated by precocious de novo methylation in clones (Dean et al., 2001). This abnormal methylation transition in cloned embryos could be due to the specific features of the somatic chromatin structure and/or defective regulation of DNMTs. For example, cloned mouse embryos expressed the somatic form of DNMT1 at abnormally high level and showed 
Table 3. DNA methylation status in cloned mammals

\begin{tabular}{|c|c|c|c|c|c|}
\hline Reference & Species & Donor cells & DNA sequence & Degree of DNA methylation $^{a}$ & Detection method \\
\hline \multirow{2}{*}{ Kang et al., 2001b } & Pig & Fetal fibroblasts & Centromeric satellite & Embryos: $\mathrm{C}=\mathrm{A}$ & Bisulfite \\
\hline & & & PRE-1 (euchromatic repeat) & Embryos $\mathrm{C}<\mathrm{A}$ & \\
\hline Dean et al., 2001 & Bovine & Fetal fibroblasts & Whole genome & Embryos: $\mathrm{C}>\mathrm{A}$ & Immunofluorescence ${ }^{b}$ \\
\hline Bourc'his et al., 2001 & Bovine & Adult fibroblasts & Whole genome & Embryos: $\mathrm{C}>\mathrm{A}$ & Immunofluorescence $^{b}$ \\
\hline Kang et al., 2001a & Bovine & Fetal fibroblasts & $\begin{array}{l}\text { Satellite I, Satellite II, SINE } \\
\text { and } 18 \mathrm{~S} \text { rRNA }\end{array}$ & In all sequences, Embryos $\mathrm{D}=\mathrm{C}>\mathrm{A}$ & Bisulfite \\
\hline Kang et al., 2002 & Bovine & Fetal fibroblasts & Tissue specific promoters & Embryos: $\mathrm{C}=\mathrm{A}$ & Bisulfite \\
\hline \multirow[t]{4}{*}{ Cezar et al., 2003} & Bovine & Genital ridge cells & Whole genome & Summary of 4 donor cell types & $\begin{array}{l}\text { Reverse phase HPLC, } \\
\text { restriction enzyme }\end{array}$ \\
\hline & & Fetal skin cells & & Aborted fetuses: $\mathrm{C}<<\mathrm{A}$ & \\
\hline & & Adult skin cells & & Live fetuses: $\mathrm{C}<\mathrm{A}$ & \\
\hline & & Fetal and adult cumulus cells & & Adults: $\mathrm{C}=\mathrm{A}$ & \\
\hline
\end{tabular}

A: age-matched controls derived from fertilization, C: cloned animals and D: the donor animals.

Immunofluorescence with anti-5-methylcytosine antibody.

defective nucleo-cytoplasmic translocation of the oocyte form of DNMT1 (Chung et al., 2003). Culture conditions of the cloned embryos are also known to affect DNA methylation as shown by loss of methylation in the regulatory $\mathrm{CpG}$ site of the $H 19$ gene depending on the culture medium of the embryos (Doherty et al., 2000).

DNA methylation of imprinted genes is established during germ cell development and is protected from the genome-wide demethylation and re-methylation in early development by an unknown mechanism ( $\mathrm{Li}, 2002)$. It is intriguing to understand whether methylation imprinting in the donor somatic nuclei is protected from the global changes of DNA methylation in the early embryos as effectively as that in the fertilized nuclei. While Inoue and colleagues found normal allele-specific expression of seven imprinted genes in mouse embryos obtained from Sertoli cells (Inoue et al., 2002), two other groups reported grossly disrupted imprinting in cumulus cell clones (Humpherys et al., 2002; Mann et al., 2003). This abnormality in the imprinting status may suggest susceptibility of the methylation imprinting in the somatic nuclei to the global methylation changes during early embryogenesis. Epigenetic markers for the inactive $\mathrm{X}$ chromosome can also be erased and re-established on either X chromosome in cloning (Eggan et al., 2000) with the exception of some X-linked genes (Xue et al., 2002). ES cellderived mouse clones show a striking variation in the DNA methylation pattern and imprinted gene expression, perhaps reflecting the instability of DNA methylation during the ES cell culture. In spite of this, some ES cell-derived clones developed to term implying that the epigenetic noise paused by aberrant DNA methylation and imprinting can be compensated by other mechanisms (Humpherys et al., 2001; Jaenisch et al., 2002). This notion is consistent with the routine success in producing ES cell chimeras in transgenic experiments.

\section{Histone modifications in cloned animals}

Global release and uptake of linker histone $\mathrm{H} 1$ is another challenge for the donor nuclei during the nuclear reprogramming. The histone $\mathrm{H} 1$ exists at a very low level in mature mouse oocytes and gradually becomes abundant around the 4-cell stage (Clarke et al., 1997; Adenot et al., 2000). Following this temporal profile, blastomere nuclei lose histone $\mathrm{H} 1$ upon injection into oocytes and reacquire histone $\mathrm{H} 1$ during the subsequent development (Bordignon et al., 2001). This DNA replication-independent transition of the histone $\mathrm{H} 1$ level was also observed in bovine clones (Bordignon et al., 1999). In Xenopus somatic nuclei incubated in egg extract, the molecular chaperone nucleoplasmin is responsible for the exchange of the somatic linker histone with the egg type linker histone B4 (Dimitrov and Wolffe, 1996). It is likely that mammalian nucleoplasmin (Burns et al., 2003) is involved in the loss of histone $\mathrm{H} 1$ from the donor nuclei, although its physiological meaning is unknown.

Alteration of histone modifications is also an important aspect of chromatin remodeling in cloning. Histones receive a number of covalent modifications including acetylation, methylation, phosphorylation, ubiquitination and ADP-ribosylation at the amino termini protruding from the chromatin core. A specific combination of these histone modifications on a given gene provides a recognition site for interacting molecules and thus contributes to regulating the gene activity (histone code hypothesis) (Strahl and Allis, 2000; Jenuwein and Allis, 2001). Bovine oocytes and early embryos express several histone acetylases and deacetylases with some variability in the transcript levels depending on the developmental stages (McGraw et al., 2003). In mouse oocytes, histone $\mathrm{H} 3$ and $\mathrm{H} 4$ are globally deacetylated on several lysines at the metaphase II of the second meiosis, which was reproduced in somatic nuclei transferred into the same stage of oocytes (Kim et al., 2003). This genomewide decrease of histone acetylation may contribute to the erasure of the previous gene expression patterns specific to the donor cell differentiation.

Methylation on histone H3 lysine 9 (H3-K9) is usually associated with gene inactivation and acetylation on H3-K9 is linked with gene activation (Fischle et al., 2003). Fertilized control mouse embryos become hypoacetylated on H3-K9 at the 4-cell stage and are gradually hyperacetylated after the 8-cell stage (Santos et al., 2003). In contrast, cloned embryos retain hyperacetylation on H3-K9 throughout these stages. At the blastocyst stage, the cloned embryos show hypermethylation on H3-K9 in the trophectoderm compared with the controls. The 
Table 4. Telomere length in cloned mammals

\begin{tabular}{|c|c|c|c|c|c|}
\hline Reference & Species & Donor cells & Number of cloned animals & Telomere length in clones ${ }^{\mathrm{a}}$ & Telomere activity in clones \\
\hline Shiels et al., 1999 & Sheep & Mammary epithelial cells & 3 & $\mathrm{D}=\mathrm{C}<\mathrm{A}$ & Not tested \\
\hline Wakayama et al., 2000 & Mouse & Cumulus cells & 35 & $\mathrm{D}<\mathrm{C}$ & Not tested \\
\hline Tian et al., 2000 & Bovine & Adult fibroblasts and cumulus cells & 10 & $\mathrm{D}<\mathrm{C}=\mathrm{A}$ & Detected \\
\hline Lanza et al., 2000 & Bovine & Senescent fibroblasts & 6 & $\mathrm{D}<\mathrm{C}>\mathrm{A}$ & Detected \\
\hline Betts et al., 2001 & Bovine & $\begin{array}{l}\text { Adult fibroblasts } \\
\text { Fetal fibroblasts } \\
\text { Granulosa cells }\end{array}$ & Total 21 & $\mathrm{D}<\mathrm{C}=\mathrm{A}$ & Detected \\
\hline \multirow[t]{5}{*}{ Miyashita et al., 2002} & Bovine & Oviductal epithelial cells & 9 & $\mathrm{D}>\mathrm{C}<\mathrm{A}$ & Not tested \\
\hline & & Mammary epithelial cells & 1 & $\mathrm{D}>\mathrm{C}<\mathrm{A}$ & Not tested \\
\hline & & Muscle cells & 2 & $\mathrm{D}=\mathrm{C}<\mathrm{A}$ & Not tested \\
\hline & & Skin fibroblasts & 2 & $\mathrm{D}=\mathrm{C}<\mathrm{A}$ & Not tested \\
\hline & & Blastomere cells & 6 & $\mathrm{C}>\mathrm{A}$ & Not tested \\
\hline Clark et al., 2003 & Sheep & Fetal fibroblasts & 2 & $\mathrm{D}<\mathrm{C}<\mathrm{A}$ & Not tested \\
\hline
\end{tabular}

detailed enzymology responsible for these transitions of histone acetylation and methylation in early embryos is not yet available, but these aberrant histone modifications should almost certainly affect expression of a number of genes.

\section{Telomere restoration in clones}

Telomeres are DNA-protein complexes at the ends of eukaryotic chromosomes essential for chromosomal integrity and normal cell growth (McEachern et al., 2000; Blasco, 2002). Vertebrate telomere DNA is composed of tandem repeats of the sequence TTAGGG and a 3'-overhang that forms a t-loop with the double-stranded DNA protecting the $3^{\prime}$ end of telomeres. Because conventional DNA polymerases cannot replicate the lagging strand at the $5^{\prime}$ end, telomeric DNA is progressively lost with each round of cell division, $50-150$ base pairs per cell division in human cells, unless the cells express the ribonucleoprotein complex telomerase. The enzymatic core of telomerase consists of the reverse transcriptase TERT (telomerase reverse transcriptase) and its template RNA TR (telomerase $\underline{R} N A$ ). While TR is ubiquitously expressed, TERT expression is limited to germ cells and stem cells in the normal human body. When telomeres become shorter than the critical threshold in somatic cells due to a lack of TERT, p53- and Rb-regulated DNA damage responses trigger growth arrest (replicative senescence) (Maser and DePinho, 2002). If TP53 and RB are inactivated, these cells can bypass this growth arrest, but the cells will eventually die because of massive chromosome end fusions triggered by the cumulative telomere loss (crisis).

The telomerase activity is subjected to multiple levels of regulatory mechanisms (Blasco, 2002; Kyo and Inoue, 2002). Transcriptional regulation of TERT by c-Myc, Max and Sp1 is one of the most critical control mechanisms. Alternative splicing of TERT also regulates the telomerase activity by producing more than six forms of transcripts including truncated forms and dominant-negative forms of TERT. Subcellular localization of TERT adds another layer of regulation to the telomerase activity. For instance, telomerase activity in activated T cells is not dependent on the total TERT protein level, rather the activ- ity is defined by nuclear translocation of TERT accompanied by phosphorylation (Liu et al., 2001). While transfected TERT is localized in the nucleoli in normal cells and released into nucleoplasm only in the $\mathrm{S}$ phase, it is always widely distributed in the cancer cell nucleoplasm (Wong et al., 2002). In addition to these direct modifications of TERT, a number of telomere binding proteins play essential roles in modulating the telomere length (Blasco, 2002). For example, TRF1 and TRF2 bind to the TTAGGG repeats and negatively regulate the telomere length through interactions with other proteins on telomeric DNA (de Lange, 2002).

Since telomere length is tightly linked with cellular senescence, it is intriguing to examine whether shortened telomeres in somatic nuclei can be restored in nuclear cloning as one aspect of re-juvenilization at the cellular level. A comparison of telomere length among donors, clones and age-matched controls was reported by several groups (Table 4). These results indicate that shortened adult cell telomeres can be restored during early development of cloned animals but the degree of telomere elongation is quite variable. Even in a single study, there was significant variation in telomere length among individual clones and among different tissues isolated from a single clone (Betts et al., 2001; Miyashita et al., 2002), underscoring the complexity and difficulty of telomere length control in clones. If aborted embryos, which potentially harbor telomeres with extremely abnormal length, are included, the efficiency of telomere restoration may be even less than what is being reported. It is not known whether the telomere elongation in clones is a secondary effect of non-specifically activated telomerase or a regulated telomere restoration reflecting the cell's effort to compensate for defective telomeres.

To understand the functional consequences of telomere restoration, two groups examined whether the replicative lifespan of senescent cells could be elongated by nuclear cloning. Lanza and colleagues found that clone-derived bovine fibroblast cells, which contained fully restored telomeres comparable to the age-matched controls, showed longer proliferative lifespan than the senescent donor fibroblast cells (Lanza et al., 2000). However, when Clark and colleagues tested cloned sheep fibroblast cells that harboured partially restored telomeres, the prolifera- 
tive lifespan of the cells was not extended (Clark et al., 2003). Thus, it remains to be examined to what extent the restored telomeres can influence the proliferative lifespan of these cells. It is also still unclear whether the resetting of proliferative lifespan of isolated cells has something to do with the lifespan of cloned animals. When whole embryonic extract was tested, the temporal profile of the telomerase activity during development was similar in cloned bovine embryos and fertilized embryos (Xu and Yang, 2001). Because a number of factors contribute to define the telomerase activity and telomere length in vivo as described above, the next step will be to examine individual accessory factors of the telomerase complex and subnuclear localization of TERT in cloned animals.

\section{Conclusion}

To be successful, clones have to erase the previous differentiation memory and establish embryo-specific gene expression profiles within a short period of time. This is accomplished through large-scale reorganization of chromatin structure and functions, as exemplified by genome-wide DNA methylation and re-methylation, adjustment of expression level for im- printed genes, reactivation of inactive $\mathrm{X}$ chromosome genes, global changes of histone modifications and exchange of linker histones. They also have to repair shortened telomeres as an essential step to restore replicative competence. It is almost inconceivable that differentiated cell nuclei can achieve this daunting task, albeit with extremely low efficiency. Some of the successful clones may have been derived from nuclei of stem cells embedded within somatic tissues, requiring less extensive nuclear reprogramming. The rare occurrence of stem cells in these tissues may explain the low efficiency of cloning and this possibility needs to be carefully examined using strict criteria for the donor cell differentiation. If creation of perfectly normal animals is the goal of cloning, it may be quite difficult, if not impossible (Rhind et al., 2003), but if the goal of the cloning study is to understand how the embryonic environment is trying to reprogram the differentiated nuclei, then the study will be a precious source of insight into the normal cell differentiation mechanisms.

\section{Acknowledgements}

We thank Justin Wudel for his critical comments on the manuscript.

\section{References}

Adenot PG, Campion E, Legouy E, Allis CD, Dimitrov S, Renard J, Thompson EM: Somatic linker histone $\mathrm{H} 1$ is present throughout mouse embryogenesis and is not replaced by variant $\mathrm{H} 1$ degrees. $\mathrm{J} \mathrm{Cell}$ Sci 113:2897-2907 (2000).

Baguisi A, Behboodi E, Melican DT, Pollock JS, Destrempes MM, Cammuso C, Williams J, Nims SD, Porter CA, Midura P, et al: Production of goats by somatic cell nuclear transfer. Nat Biotechnol 17:456-461 (1999).

Betthauser J, Forsberg E, Augenstein M, Childs L, Eilertsen K, Enos J, Forsythe T, Golueke P, Jurgella G, Koppang R, et al: Production of cloned pigs from in vitro systems. Nat Biotechnol 18:10551059 (2000).

Betts D, Bordignon V, Hill J, Winger Q, Westhusin M, Smith L, King W: Reprogramming of telomerase activity and rebuilding of telomere length in cloned cattle. Proc Natl Acad Sci USA 98:1077-1082 (2001).

Bird A: DNA methylation patterns and epigenetic memory. Genes Dev 16:6-21 (2002).

Blasco MA: Telomerase beyond telomeres. Nat Rev Cancer 2:627-633 (2002).

Boiani M, Eckardt S, Scholer HR, McLaughlin KJ: Oct4 distribution and level in mouse clones: consequences for pluripotency. Genes Dev 16:1209_ 1219 (2002).

Bordignon V, Clarke HJ, Smith LC: Developmentally regulated loss and reappearance of immunoreactive somatic histone $\mathrm{H} 1$ on chromatin of bovine morula-stage nuclei following transplantation into oocytes. Biol Reprod 61:22-30 (1999).

Bordignon V, Clarke HJ, Smith LC: Factors controlling the loss of immunoreactive somatic histone $\mathrm{H} 1$ from blastomere nuclei in oocyte cytoplasm: a potential marker of nuclear reprogramming. Dev Biol 233:192-203 (2001).

Bortvin A, Eggan K, Skaletsky H, Akutsu H, Berry DL, Yanagimachi R, Page DC, Jaenisch R: Incomplete reactivation of Oct4-related genes in mouse embryos cloned from somatic nuclei. Development 130:1673-1680 (2003).
Bourc'his D, Le Bourhis D, Patin D, Niveleau A, Comizzoli P, Renard JP, Viegas-Pequignot E: Delayed and incomplete reprogramming of chromosome methylation patterns in bovine cloned embryos. Curr Biol 11:1542-1546 (2001).

Briggs R, King TJ: Transplantation of living nuclei from blastula cells into enucleated frogs' eggs. Proc Natl Acad Sci USA 38:455-463 (1952).

Burns KH, Viveiros MM, Ren Y, Wang P, DeMayo FJ, Frail DE, Eppig JJ, Matzuk MM: Roles of NPM2 in chromatin and nucleolar organization in oocytes and embryos. Science 300:633-636 (2003).

Byrne JA, Simonsson S, Gurdon JB: From intestine to muscle: nuclear reprogramming through defective cloned embryos. Proc Natl Acad Sci USA 99:60596063 (2002).

Byrne JA, Simonsson S, Western PS, Gurdon JB: Nuclei of adult mammalian somatic cells are directly reprogrammed to Oct-4 stem cell gene expression by amphibian oocytes. Curr Biol 13:1206-1213 (2003).

Campbell KH: Nuclear transfer in farm animal species. Semin Cell Dev Biol 10:245-252 (1999).

Cezar GG, Bartolomei MS, Forsberg EJ, First NL, Bishop MD, Eilertsen KJ: Genome-wide epigenetic alterations in cloned bovine fetuses. Biol Reprod 68:1009-1014 (2003).

Chambers I, Colby D, Robertson M, Nichols J, Lee S, Tweedie S, Smith A: Functional expression cloning of Nanog, a pluripotency sustaining factor in embryonic stem cells. Cell 113:643-655 (2003).

Chan AP, Gurdon JB: Nuclear transplantation from stably transfected cultured cells of Xenopus. Int J Dev Biol 40:441-451 (1996).

Chesne P, Adenot PG, Viglietta C, Baratte M, Boulanger L, Renard JP: Cloned rabbits produced by nuclear transfer from adult somatic cells. Nat Biotechnol 20:366-369 (2002).
Chung YG, Ratnam S, Chaillet JR, Latham KE: Abnormal regulation of DNA methyltransferase expression in cloned mouse embryos. Biol Reprod 69:146-153 (2003)

Cibelli JB, Stice SL, Golueke PJ, Kane JJ, Jerry J, Blackwell C, Ponce de Leon FA, Robl JM: Cloned transgenic calves produced from nonquiescent fetal fibroblasts. Science 280:1256-1258 (1998).

Clark AJ, Ferrier P, Aslam S, Burl S, Denning C, Wylie D, Ross A, de Sousa P, Wilmut I, Cui W: Proliferative lifespan is conserved after nuclear transfer. Nat Cell Biol 5:535-538 (2003).

Clarke HJ, Bustin M, Oblin C: Chromatin modifications during oogenesis in the mouse: removal of somatic subtypes of histone H1 from oocyte chromatin occurs post-natally through a post-transcriptional mechanism. J Cell Sci 110:477-487 (1997).

Daniels R, Hall V, Trounson AO: Analysis of gene transcription in bovine nuclear transfer embryos reconstructed with granulosa cell nuclei. Biol Reprod 63:1034-1040 (2000)

Daniels R, Hall VJ, French AJ, Korfiatis NA, Trounson AO: Comparison of gene transcription in cloned bovine embryos produced by different nuclear transfer techniques. Mol Reprod Dev 60:281-288 (2001).

de Lange T: Protection of mammalian telomeres. Oncogene 21:532-540 (2002).

Dean W, Santos F, Stojkovic M, Zakhartchenko V, Walter J, Wolf E, Reik W: Conservation of methylation reprogramming in mammalian development: aberrant reprogramming in cloned embryos. Proc Natl Acad Sci USA 98:13734-13738 (2001).

Dean W, Santos F, Reik W: Epigenetic reprogramming in early mammalian development and following somatic nuclear transfer. Semin Cell Dev Biol 14:93-100 (2003).

Dimitrov S, Wolffe AP: Remodeling somatic nuclei in Xenopus laevis egg extracts: molecular mechanisms for the selective release of histones $\mathrm{H} 1$ and $\mathrm{H} 1(0)$ from chromatin and the acquisition of transcriptional competence. EMBO J 15:5897-5906 (1996). 
Doherty AS, Mann MR, Tremblay KD, Bartolomei MS, Schultz RM: Differential effects of culture on imprinted $\mathrm{H} 19$ expression in the preimplantation mouse embryo. Biol Reprod 62:1526-1535 (2000).

Eggan K, Akutsu H, Hochedlinger K, Rideout WM 3rd, Yanagimachi R, Jaenisch R: X-Chromosome inactivation in cloned mouse embryos. Science 290 1578-1581 (2000).

Fischle W, Wang Y, Allis CD: Histone and chromatin cross-talk. Curr Opin Cell Biol 15:172-183 (2003).

Galli C, Lagutina I, Crotti G, Colleoni S, Turini P, Ponderato N, Duchi R, Lazzari G: Pregnancy: a cloned horse born to its dam twin. Nature 424:635 (2003).

Gonda K, Fowler J, Katoku-Kikyo N, Haroldson J, Wudel J, Kikyo N: Reversible disassembly of somatic nucleoli by the germ cell proteins FRGY2a and FRGY2b. Nat Cell Biol 5:205-210 (2003).

Gurdon JB: Nuclear transplantation in eggs and oocytes. J Cell Sci 4:287-318 (1986).

Gurdon JB: Genetic reprogramming following nuclea transplantation in Amphibia. Semin Cell Dev Biol 10:239-243 (1999).

Gurdon JB, Byrne JA: The first half-century of nuclear transplantation. Proc Natl Acad Sci USA 100: 8048-8052 (2003)

Hochedlinger K, Jaenisch R: Monoclonal mice generated by nuclear transfer from mature $\mathrm{B}$ and $\mathrm{T}$ donor cells. Nature 415:1035-1038 (2002a).

Hochedlinger K, Jaenisch R: Nuclear transplantation: lessons from frogs and mice. Curr Opin Cell Bio 14:741-748 (2002b).

Humpherys D, Eggan K, Akutsu H, Hochedlinger K, Rideout WM 3rd, Biniszkiewicz D, Yanagimachi $\mathrm{R}$, Jaenisch R: Epigenetic instability in ES cells and cloned mice. Science 293:95-97 (2001).

Humpherys D, Eggan K, Akutsu H, Friedman A, Hochedlinger K, Yanagimachi R, Lander ES, Golub TR Jaenisch R: Abnormal gene expression in cloned mice derived from embryonic stem cell and cumulus cell nuclei. Proc Natl Acad Sci USA 99:1288912894 (2002).

Inoue K, Kohda T, Lee J, Ogonuki N, Mochida K, Noguchi Y, Tanemura K, Kaneko-Ishino T, Ishino F, Ogura A: Faithful expression of imprinted genes in cloned mice. Science 295:297 (2002).

Jaenisch R, Eggan K, Humpherys D, Rideout WM 3rd, Hochedlinger K: Nuclear cloning, stem cells, and genomic reprogramming. Cloning Stem Cells 4:389-396 (2002).

Jenuwein T, Allis CD: Translating the histone code. Science 293:1074-1080 (2001)

Kang YK, Koo DB, Park JS, Choi YH, Chung AS, Lee KK, Han YM: Aberrant methylation of donor genome in cloned bovine embryos. Nat Genet 28:173-177 (2001a).

Kang YK, Koo DB, Park JS, Choi YH, Kim HN, Chang WK, Lee KK, Han YM: Typical demethylation events in cloned pig embryos. Clues on species-specific differences in epigenetic reprogramming of a cloned donor genome. J Biol Chem 276:39980-39984 (2001b).

Kang YK, Park JS, Koo DB, Choi YH, Kim SU, Lee KK, Han YM: Limited demethylation leaves mosaic-type methylation states in cloned bovine preimplantation embryos. EMBO J 21:1092-1100 (2002).

Kato Y, Tani T, Sotomaru Y, Kurokawa K, Kato J, Doguchi H, Yasue H, Tsunoda Y: Eight calves cloned from somatic cells of a single adult. Science 282:2095-2098 (1998).

Kikyo N, Wolffe AP: Reprogramming nuclei: insights from cloning, nuclear transfer and heterokaryons. J Cell Sci 113:11-20 (2000).

Kim JM, Liu H, Tazaki M, Nagata M, Aoki F: Changes in histone acetylation during mouse oocyte meiosis. J Cell Biol 162:37-46 (2003).
Kyo S, Inoue M: Complex regulatory mechanisms of telomerase activity in normal and cancer cells: how can we apply them for cancer therapy? Oncogene 21:688-697 (2002).

Lanza RP, Cibelli JB, Blackwell C, Cristofalo VJ, Francis MK, Baerlocher GM, Mak J, Schertzer M, Chavez EA, Sawyer N, et al: Extension of cell lifespan and telomere length in animals cloned from senescent somatic cells. Science 288:665-669 (2000).

Li E: Chromatin modification and epigenetic reprogramming in mammalian development. Nat Rev Genet 3:662-673 (2002)

Liu K, Hodes RJ, Weng N: Cutting edge: telomerase activation in human $\mathrm{T}$ lymphocytes does not require increase in telomerase reverse transcriptase (hTERT) protein but is associated with hTERT phosphorylation and nuclear translocation. J Immunol 166:4826-4830 (2001).

Mann MR, Chung YG, Nolen LD, Verona RI, Latham KE, Bartolomei MS: Disruption of imprinted gene methylation and expression in cloned preimplantation stage mouse embryos. Biol Reprod 69:902914 (2003).

Maser RS, DePinho RA: Connecting chromosomes, crisis, and cancer. Science 297:565-569 (2002).

Mayer W, Niveleau A, Walter J, Fundele R, Haaf T: Demethylation of the zygotic paternal genome. Nature 403:501-502 (2000).

McEachern MJ, Krauskopf A, Blackburn EH: Telomeres and their control. Annu Rev Genet 34:331358 (2000).

McGraw S, Robert C, Massicotte L, Sirard MA: Quantification of histone acetyltransferase and histone deacetylase transcripts during early bovine embryo development. Biol Reprod 68:383-389 (2003).

McLaren A: Cloning: pathways to a pluripotent future. Science 288:1775-1780 (2000).

Mitsui K, Tokuzawa Y, Itoh H, Segawa K, Murakami M, Takahashi K, Maruyama M, Maeda M, Yamanaka S: The homeoprotein Nanog is required for maintenance of pluripotency in mouse epiblast and ES cells. Cell 113:631-642 (2003)

Miyashita N, Shiga K, Yonai M, Kaneyama K, Kobayashi S, Kojima T, Goto Y, Kishi M, Aso H, Suzuki T, et al: Remarkable differences in telomere lengths among cloned cattle derived from different cell types. Biol Reprod 66:1649-1655 (2002).

Mullins LJ, Wilmut I, Mullins JJ: Nuclear Transfer in Rodents. J Physiol, published online on October 17,2003 as $10.1113 /$ jphysiol.2003.049742.

Oback B, Wells D: Donor cells for nuclear cloning: many are called, but few are chosen. Cloning Stem Cells 4:147-168 (2002).

Onishi A, Iwamoto M, Akita T, Mikawa S, Takeda K, Awata T, Hanada H, Perry AC: Pig cloning by microinjection of fetal fibroblast nuclei. Science 289:1188-1190 (2000)

Pesce M, Scholer HR: Oct-4: gatekeeper in the beginnings of mammalian development. Stem Cells 19: 271-278 (2001)

Polejaeva IA, Chen SH, Vaught TD, Page RL, Mullins J, Ball S, Dai Y, Boone J, Walker S, Ayares DL, et al: Cloned pigs produced by nuclear transfer from adult somatic cells. Nature 407:86-90 (2000).

Rhind SM, King TJ, Harkness LM, Bellamy C, Wallace W, DeSousa P, Wilmut I: Cloned lambs-lessons from pathology. Nat Biotechnol 21:744-745 (2003).

Rideout WM 3rd, Eggan K, Jaenisch R: Nuclear cloning and epigenetic reprogramming of the genome. Science 293:1093-1098 (2001).

Roh S, Guo J, Malakooti N, Morrison JR, Trounson AO, Du ZT: Birth of rats by nuclear transplantation using 2-cell stage embryo as donor nucleus and recipient cytoplasm. Theriogenology 59:283 (2003).
Santos F, Hendrich B, Reik W, Dean W: Dynamic reprogramming of DNA methylation in the early mouse embryo. Dev Biol 241:172-182 (2002).

Santos F, Zakhartchenko V, Stojkovic M, Peters A, Jenuwein T, Wolf E, Reik W, Dean W: Epigenetic marking correlates with developmental potentia in cloned bovine preimplantation embryos. Curr Biol 13:1116-1121 (2003).

Shiels PG, Kind AJ, Campbell KH, Waddington D, Wilmut I, Colman A, Schnieke AE: Analysis of telomere lengths in cloned sheep. Nature 399:316317 (1999).

Shin T, Kraemer D, Pryor J, Liu L, Rugila J, Howe L, Buck S, Murphy K, Lyons L, Westhusin M: A cat cloned by nuclear transplantation. Nature $415: 859$ (2002).

Solter D: Mammalian cloning: advances and limitations. Nat Rev Genet 1:199-207 (2000).

Strahl BD, Allis CD: The language of covalent histone modifications. Nature 403:41-45 (2000).

Suemizu H, Aiba K, Yoshikawa T, Sharov AA, Shimozawa N, Tamaoki N, Ko MS: Expression profiling of placentomegaly associated with nuclear transplantation of mouse ES cells. Dev Biol 253:36-53 (2003).

Sun FZ, Moor RM: Nuclear transplantation in mammalian eggs and embryos. Curr Top Dev Biol 30:147-176 (1995).

Tamashiro KL, Wakayama T, Akutsu H, Yamazaki Y, Lachey JL, Wortman MD, Seeley RJ, D'Alessio DA, Woods SC, Yanagimachi R, Sakai RR: Cloned mice have an obese phenotype not transmitted to their offspring. Nat Med 8:262-267 (2002).

Tian XC, Xu J, Yang X: Normal telomere lengths found in cloned cattle. Nat Genet 26:272-273 (2000).

Wade PA, Kikyo N: Chromatin remodeling in nuclear cloning. Eur J Biochem 269:2284-2287 (2002).

Wakayama T, Yanagimachi R: Cloning the laboratory mouse. Semin Cell Dev Biol 10:253-258 (1999).

Wakayama T, Perry ACF, Zucotti M, Johnson KR, Yanagimachi R: Full term development of mice from enucleated oocytes injected with cumulus cell nuclei. Nature 394:369-374 (1998)

Wakayama T, Shinkai Y, Tamashiro KL, Niida H, Blanchard DC, Blanchard RJ, Ogura A, Tanemura $\mathrm{K}$, Tachibana M, Perry AC, et al: Cloning of mice to six generations. Nature 407:318-319 (2000).

Wilmut I, Schnieke AE, McWhir J, Kind AJ, Campbell $\mathrm{KH}$ : Viable offspring derived from fetal and adult mammalian cells. Nature 385:810-813 (1997).

Wong JM, Kusdra L, Collins K: Subnuclear shuttling of human telomerase induced by transformation and DNA damage. Nat Cell Biol 4:731-736 (2002).

Woods GL, White KL, Vanderwall DK, Li GP, Aston KI, Bunch TD, Meerdo LN, Pate BJ: A mule cloned from fetal cells by nuclear transfer. Science 301:1063 (2003)

Wrenzycki C, Wells D, Herrmann D, Miller A, Oliver J, Tervit R, Niemann H: Nuclear transfer protocol affects messenger RNA expression patterns in cloned bovine blastocysts. Biol Reprod 65:309317 (2001).

$\mathrm{Xu}$ J, Yang X: Telomerase activity in early bovine embryos derived from parthenogenetic activation and nuclear transfer. Biol Reprod 64:770-774 (2001).

Xue F, Tian XC, Du F, Kubota C, Taneja M, Dinnyes A, Dai Y, Levine H, Pereira LV, Yang X: Aberrant patterns of $\mathrm{X}$ chromosome inactivation in bovine clones. Nat Genet 31:216-220 (2002).

Young LE, Sinclair KD, Wilmut I: Large offspring syndrome in cattle and sheep. Rev Reprod 3:155-163 (1998).

Zhou Q, Renard J-P, Le Friec G, Brochard V, Beaujean N, Cherifi Y, Fraichard A, Cozzi J: Generation of fertile cloned rats by regulating oocytes activation. Science 302:1179 Epub (2003). 